\title{
TASDIKTEN DOĞAN SORUMLULUK VE DENETIM RISKI
}

\author{
Prof. Dr. Celal KEPEKÇI*
}

3568 sayılı Serbest Muhasebecilik, Serbest Muhasebeci Mali Müsavirlik ve Yeminli Mali Müşavirlik Kanununun 12 nci maddesi yeminli mali müşavirlerin tasdik işlerini tanımlamış; yeminli mali müşavirlerin tasdik edecekleri belgeleri, tasdik konularını ve tasdike ilişkin usul ve esaslan belirleme yetkisini Maliye Bakanlı̆̆ına vermiştir. Bu madde hükmüne göre, "yeminli mali müşavirler gerçek ve tüzel kişilerin veya bunların teşebbbüs ve işletmelerinin mali tablolarının ve beyannamelerinin mevzuat hükümlerine, muhasebe prensipleri ile muhasebe standartlarına uygunluğunu ve hesapların denetim standartlanna göre incelendiğini tasdik ederler." Madde metninden yeminli mali müşavirlerin kendi yaptuklan incelemeleri kendilerinin tasdik edeceł̧i anlamı çıkmaktadır: Bu ifadenin verine "yeminli mali müşavirler mali tablolann ve beyannamelerin mevzuat hükümleri ve muhasebe standartlarına uygunluğunu tasdik ederler ve hesaplan denetim standartlanna göre denetlediklerini beyan ederler." seklinde bir ifadenin yer alması gerekirdi.

Sőzkonusu maddenin birinci fıkrasında tasdik konusu; "mali tablolar ve beyannameler" olarak ifade edilirken, maddenin ikinci fukrasında ve bu maddeye göre çıkanlan yơnetmelikte "tasdik edilecek belgeler" kavramına yer verilmiştir. 14 no.lu Genel Tebliğde "yıllık gelir ve kurumlar vergisi beyannameleri ile bunlara ekli mali tablo ve bildirimlerin" tasdik kapsamına alındığı açıklanmışur.

Ayrıca, ayni maddede yeminli mali müşavirlerin, yaptıkları tasdikin doğru olmaması halinde, tasdikin kapsamı ile sınırı olmak üzere, ziyaa uğratulan vergilerden ve kesilecek cezalardan mükellefle birlikte müşıreken ve müteselsilen sorumlu olacaklan ifade edilmiştir. Sozkonusu maddede belirtilen sorumluluk, vergi kaybı ve bundan doğacak cezalarla sınırlandırılmıştır: Kanun metninde yeminli mali müşavirlere, tasdikten dolayı denetlenene ve uçüncü kişilere karşı sorumluluk yükleyen ơzel bir hüküm getirilmemiştir. Yalnızca, sözkonusu maddenin son fıkrasında bu Kanun hükümlerine göre meslek icra edenlerin vergi kanunları ve diğer kanunlardaki sorumlulukłannın saklı olduğu belinilmiştir. Sőzkonusu Kanunun 49. maddesinde tasdikten doğan sorumluluğun kesinleşmesi halinde aynca para ve hapis cezaları öngörülmüşı̈ür.

\footnotetext{
* A.O. SBF, Işletme Bölümü. Muhasebe-Finans Ana Bilim Dahı Oğrctim Uyesi
} 
3568 sayılı Kanun, dénetim yapma yetkisini vercliği serbest muhasebeci mali müşavir ve yeminli mali müşavirlerin yaptıkları denetimlerden dogan sorumluluklarına ilişkin olarak, 43 üncü madde hariç, hiçbir hüküm içermemektedir.

3568 sayılı Kanun, yeminli mali müşavirlerin tasdikten doğan sorumluluklarının hangi koşullarda ve ne zaman kesinleştiģini tanımlamad. maddesine gơre Maliye Bakanlı̆ınca çıkarılan Yonetmelikls' ve bu Yơnetmeliğin 19 uncu maddesine göre - çıkarılmış 13 tebliğde sorumluluğun bọlirlenmesi ve kesinleşmesine ilişkin bir hüküm yer almamaktadır. 23 Şubat 1995 tarihli Resmi Gazete'de yayımlanan 14 sıra no.lu Tebliğde müşterek ve müteselsil sorumluluğun tesbiti başlığı altunda tasdikten doğan sorumluluk açıklanmışur. Teblĭg hükmii uyarınca, Maliye Bakanlığı̆ vergi denetim elemanlannca yaplacak vergi incelemesi sonucunda bir matrah veya vergi farkı ortaya çıkı̆̆ı takdirde, denetim elemanları, yeminli mali müşavirlerin sorumluluklarının tesbiti amacıyla, bulunan matrah veya vergi farkı ile yeminli mali müşavirlerin yukanda belirtilen sorumluluklan arasındaki iiıışkiyi, inceleme raporunda net bir şekilde ortaya koyacaklardır. Yeminli mali müşavirler.n sorumlu tutulması gereken bir durum tesbit edilmesi halinde, sözkonusu inceleme raporunun onaylı bir orneği Gelirler Genel Müdürlü̆g̈üne gönderilecektir.

Sözkonusu Tebliğe göre, müşterek ve müteselsil sorumluluğu vergi inceleme raporu ile tesbit edilen yeminli mali müşavirler nezdinde yapılacak takibat, vergi ve ceza tahakkukunun kesinleşmesinden sonra başlaulacaktur. Vergi dairelerince yapılacak olan takibat, tahakkuku kesinleşen vergi ve cezaların tahsiline y'snelik olacaktır. Sorumluluğu tesbit edilen yeminli mali müşavirlerle ilgili takibat, yesninli mạli müşavirlerin bağı̆ı olduğu vergi dairesince yerine getirilecektir.

3568 sayılı Kanunun 12 nci maddesine göre çıł:arılan Yönetmeliğin 16 ncı maddesi uyannca, yeminli mali müşavir, tasdik konust! ve belgelerin ilgili mevzuat hükümlerine uygunluğu ve gerçek durumu yansıtması yönünden onemli etkileri olabilecek hata ve hileleri düzeltecek veya ortaya çıkaracak şekilde denetimi planlamak ve yürütmekle yükümlüdür. Yönetmelikte önemli hata ve hilelerin ne olduğu tanımlanmadığı gibi, önemlilik düzeyi tutar olarak vej'a net satışların ya da vergi matrahının bir yüzdesi olarak da açıklanmamışır. Bu nedenle tasdik amacıyla yapılan denetimde yeminli mali müşavir tarafından önemsiz bulunan hata ve hileler; daha sonra vergi denetim elmanlarınca yapilacak vergi incelemesinde, lutar ve yüzde olarak aynı olsa bile, önemli görülebilir ve inccleme raporunda yemiali mali müşavirin sorumlu tutulmast istenebilir.

Sőzkonuu Yơnetmeliğin $5 \mathrm{nc}$ maddesine göræs, yeminli mali müşavirler müşterisinden gelen tasdik talebini kabul etmeden önce, iistlenecekleri tasdik işleminin kendilerine getirebileceği riski tesbit etmek; tasdik kapsam ve programını belirlemek amacıyla gerekli araşurmalan yapmak zorundadırlar. Yöneımeliğin bu maddesinde geçen risk kavramı iş riski ve denetim riski olarak ikiye ayrılabilir. Iş riski, tasdik kapsamına giren konuların ve belgelerin gerçeği yansıtmaması nederiyle yeminli mali müsavirlerin sorumlu tutulması olasılı̆̆ıdır. Is riski; yeminli mali mı̈şavirlerin tasdik ettiği tasdik kapsamina giren konu ve belgelerin vergi denetim eleınanları tarafından incelenme olasılı̌̆ına, incelendiği takdirde vergi denctim elemanlarının matrah veya vergi farkı bulma olasilığına, vergi denetim elemanlarınca bulunan matrah veya vergi farkı ile yeminli mali müşavirlerin sorumluluğu arasındaki ilişkiỵi denctim elemanının inceleme 
raporunda net bir şekilde ortaya koyma olasılığına ve yargıda vergi inceleme raporundaki görüşlerin haklı görülmesi olasılığına bağlıdır.

Denetimde risk, denetçinin denetim işlevini yerine getirmede belirli bir belirsizlik düzeyini kabul etmesi demektir. Örneğin denetçi, kantlann güvenirliğine ve iç kontrol sisteminin etkin işlediğine ilişkin belirsizliklerin var olduğunu, aynca denetim tamamlandığında mali tablolann doğru beyan edilip edilmediğine ilişkin belirsizliğin var olduğunu gözönünde bulundurur. Denetim riski, mali tablolarda onemli hata ve yolsuzluklar gizlendigi halde, denetçinin bu hata ve yolsuzluklan bulamaması sonucunda mali tablolar hakkında olumlu görüş bildirmesi olasılı̈̆ıdır. Tasdik açısından denetim riski; tasdik kapsamına giren konular ve belgeler gerçeği yansıtmadığı halde, yeminli mali müşavirlerin hata ve hileleri ortaya çıkaramaması sonucunda tasdik kapsamına giren konular ve belgelerin (mali tablolar ve beyannamelerin) tasdik edilmesi olasılığıdır.

Denetçi, hem denetimi planlama safhasında kanıt toplamak amacıyla uygulayacał̆ı denetim prosedürlerini tasarlamada, hem de denetim tamamlandığında mali tablolarn bir bütün olarak doğru beyan edilmiş olup olmadığını değerlemede denetim riskini ve önemlilik düzeyini gőzơnünde bulundurur. Yeminli mali müşavir doğru tasdik yaptığından daha fazla emin olmak isterse, kabul edeceği denetim riski daha dủşuk olacaktır. Ómeğin, \% 99 kesinlik oranı ile doğru tasdik yapılması arzu edilirse, kabul edilecek denetim riski \% 1 olacak; buna karşılık \% 95 kesinlik derecesi yeterli görülürse, denetim riski \% 5 olacakur. Denetim riski, denetlenen işletmeden, denetimin ozellił̧inden ve denetçiden kaynaklanan nedenlerle hiçbir zaman \% 0 olamaz. Bu nedenler denetim riski modelinde açıklanmışur. Denetim riski ü̧̨ tür riskin sonucudur ve aşağıdaki gibi formüle edilebilir.

Kabul Edilebilir Denetim Riski $=$ YR $\times$ KR $\times$ BR

- Yapısal risk (YR),

- Kontrol riski (KR),

- Bulgu riski (BR).

Yapısal risk, iç kontrol sistemi olmadığı varsayıldığında, belirli yapısal ve çevresel özellikleri nedeniyle hesapların ve işlemlerin hata ve yolsuzluklardan etkilenebilirlik derecesidir. Bu risk, bazı hesaplarda ve işlem türlerinde diğer hesap ve işlem türlerine göre daha yükscktir.

Kontrol riski, mevcut iç kontrol sisteminin önemli hataları ve yolsuzluklan önleyememe ve bulamama olasılığıdır.

Bulgu riski, mali tablolarda giżli kalan önemli hata ve hileleri, denetçinin, denetim prosedürleriyle bulamaması olasılığıdır. Denetçi, bulgu riskini azaltukça daha fazla kanit toplamalidir.

Kabul edilebilir denetim riski, mali tablolar bazında saptanamaz. Bu, herbir hesap ve işlem türü için ayrı ayn belirlencbilir. Ancak, bu belirleme sübjektiftir. Denetçi, kabul edilebilir denetim riskini herbir hesap ve işlem türü için saptadıktan sonra, bulgu riskini planlayabilir. Denetim riski modelinden bulgu riski hesaplanabilir. 


$$
\text { Bulgu Riski }=\frac{D R}{Y R \times K R}
$$

Denetçi, kabul edilcbilir denetim riskini \% 5, yapısıl riski \% 80 ve kontrol riskini \% 50 olarak saptarsa, bu formüle göre planlanan bulgu riski \% $12,5(0,05 / 0,80 \times 0,50)$ olacaktır. Denetçi bu düzeye uygun sayıda kanıt toplayacakiır.

Risk düzeyleri yüzde olarak saptanabileceği gibi; yüksek, orta ve düşük düzeyde gibi niteliksel kavramlarla da saptanabilir. Aşağıdaki şek.ilde çeşitli işlem grupları için risk düzeylerinin belirlenmesine ömek verilmiştir:

Çeşitli Işlem Gruplannda Risk Diizeyleri Arasındaki flişkiler

\begin{tabular}{|c|c|c|c|c|}
\hline Işlem Türleri & $\begin{array}{c}\text { Yapisal } \\
\text { Risk }\end{array}$ & $\begin{array}{c}\text { Kontrol } \\
\text { Riski }\end{array}$ & $\begin{array}{l}\text { Planlanan } \\
\text { Bulgu Riski }\end{array}$ & $\begin{array}{l}\text { Kabul Edilebilir } \\
\text { Denetim Riski }\end{array}$ \\
\hline Satı̧ ve Tahsilat & Orta & Orta & Orta & Düşük \\
\hline Satun Aḷma ve Ödeme & Yüksek & Düşük & Orta & Düşülk \\
\hline Ücret ve Personel & Düşiik & Düşüuk & Yülssek & Düşük \\
\hline Depolama & Yüksek & Yüksek & Diüşük & Düşük \\
\hline $\begin{array}{l}\text { Sermaye ve Yabancı } \\
\text { Kaynak Sağlama }\end{array}$ & Düşïk & Orta & Orta & Düşük \\
\hline
\end{tabular}

Denetçi, yapısal risk ve kontrol riski düzeylerini veri olarak kabul edecektir, bunları değiştiremez. Kabul cđebileceği denetim riski düzcyine uygun olarak ve saptadığı yapısal risk ve kontrol risklerini gözönünde bulundurarak bulgu riski düzeyini planlar ve bu düzeye uygun sayıda kanıt toplar ve değerler. Denetçi cınetleycceği hesap veya işlem türünü çok riskli bulursa ve iç kontrol sistemine güvenrıezse, yapısal risk ve kontrol riski düzeylerini maksmum $(\% 100)$ kabul eder ve denetim riski düzeyi ile bulgu riski düzeyi birbirlerine eşit olur. Bu durumda denetçi bildirdi ̧̧i görüşten veya tasdik ettiği mali tablolar ve beyannamelerden \% 100'e yakın kesinlikle emin olmak için denetim riskini ve dolayısıyla bulgu riskini \% 0'a yakın belirleyeciektir. \% 0'a yakın bulgu riski đüzeyinde ise, denetçi örnekleme yöntemleriyle değil. bir dönemin tüm belge ve kayițarını taramak suretiyle kanıt, toplayacaktır. Böyle bir denetim ekonomik olmadığı gibi pratik de olmayacakur. 